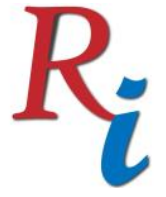

Asia Proceedings of Social Sciences

(APSS)

www.readersinsight.net/APSS

\title{
THE MAIN COMPONENT FOR DESIGNING SMART LEARNING Iman Nurjaman*
}

Faculty of Teacher Training and Education Universitas Muhammadiyah Tangerang Indonesia

\section{Yudhie Indra Gunawan}

Faculty of Teacher Training and Education Universitas Muhammadiyah Tangerang Indonesia

\section{Titi Rachmi}

Faculty of Teacher Training and Education Universitas Muhammadiyah Tangerang Indonesia

*Corrosponding author's Email: uㅏjamaniman@gmail.com

Author's Biography

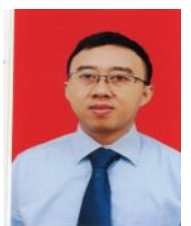

The author is a doctoral student majoring in Educational Technology at the Postgraduate of Universitas Negeri Jakarta. The author's research and writing has a lot to do with the use of technology and learning, model development and online learning. The author's activities besides lecturing are teaching in the Early Childhood Education Teacher Education study program at Universitas Muhammadiyah Tangerang and at the Open University in the Primary School Teacher Education study program. The author can be contacted via email: nurjamaniman@gmail.com

Peer-review under responsibility of $3^{\text {rd }}$ Asia International Multidisciplanry Conference 2019 editorial board (http://www.utm.my/asia/our-team/) (C) 2019 Published by Readers Insight Publisher, lat 306 Savoy Residencia, Block 3 F11/1,44000 Islamabad. Pakistan, 


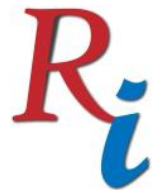

\section{Asia Proceedings of Social Sciences \\ (APSS) \\ www.readersinsight.net/APSS}

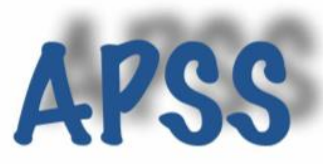

\section{Rese a r ch H i g h I igh t s}

This paper discusses key components in designing smart learning. The concept of smart learning emphasises the importance of technological design to make learning better. In fact, many different definitions can be found in almost all the articles that emphasise multiple aspects and characteristics of smart learning published since 2014 in the journal Smart Learning Environments. This finding illustrates the main components of smart learning to improve knowledge and develop smart learning designs. Based on the results of the literature review it was found that, there are some common and crucial elements identified by most researchers in this field. The first highlights that smart learning is technology. In addition to technology, there are other important components, that is self regulated learning, the needs and characteristics of learner, participation \& feedback

\section{Research Objectives}

This article aims to find the main components for designing smart learning. To achieve the objectives of the study, the literature study was conducted to find out what major components had been agreed upon by experts

\section{Methodology}

This research method is a literature study on smart learning. Literature which is a reference material starts from 2015 - 2018

\section{Results}

In general, experts agree on the main components of smart learning, If we conclude, the component is :

\section{Technology.}

The term 'smart' has been used to modify a learning environment as well as a technology(Spector, 2016)(Kravcik and Popescu, 2015)(Ibrahim, 2019). Smart, however, is a term that has long been associated with computers (Zuboff, 2015, 1988; Bell, 2017; Kallinikos, 2010).Freigang, and Schlenker, and and Kohler. Much of the relevant research concerns learning within smart cities, or smart learning that is conceptualized and determined by technology, infrastructure and the production and analysis(Lister, 2018)

of large datasets (Nikolov et al. 2016; Liu et al. 2017a; Giannakos et al. 2016)

According to Zhu et al. (2016, p. 3), "there is not a clear and unified definition of smart learning so far. Multidisciplinary researchers and educational professionals are continuously discussing the concept". In fact, many different definitions can be found in almost all the articles that emphasise multiple aspects and characteristics of smart learning published since 2014 in the journal Smart Learning Environments. However, there are some common and crucial elements identified by most researchers in this field. The first highlights that smart learning is technology(Gros, 2016).

\section{Self Regulated Learning}

MEST (2011) present the features of smart learning defined as self-directed, motivated, adaptive, resource-enriched and technology-embedded while Lee (2015) proposed that the features smart learning include formal and informal learning, social and collaborative learning, personalized and situated learning, and application and content focus.(Gros, 2016) 


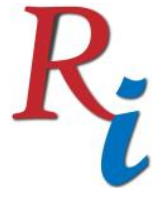

\section{Asia Proceedings of Social Sciences (APSS) \\ www.readersinsight.net/APSS}

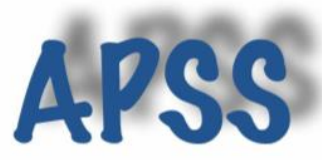

Smart learning can often be happening without any formal tutor, or even any conscious acknowledgement of it (Buchem and Pérez-Sanagustín 2013)(Lister, 2018).

From the above understanding can be interpreted students must have the ability selfgenerated ability to control, manage, and plan their learning actions (Ally, 2004). Such a regulatory process has been referred to as self-regulated learning (SRL; Zimmerman, 2008)(Broadbent and Poon, 2015)

\section{Findings}

This article finds that there are several important components that can be a component for designing smart learning. this study found that the main components of smart learning are not only limited to the previous two components, namely technology and self-regulated learning but there are other components namely

\section{Needs and Leaners Characteristic}

Smart learning must prioritize learner needs and be personal in accordance with the real conditions at that time.(Gros, 2016)(Popescu and Chen, 2017) Learners have various preferences and needs like learning styles, a prior knowledge, performance, cognitive abilities, and learning goals (Baldoni, Baroglio, \& Henze, 2005, pp. 173e212; Chrysafiadi \& Virvou, 2013; Dominic \& Francis, 2015; Q. Gu \& Sumner, 2006; Halimi, SeridiBouchelaghem, \& Faron-Zucker, 2014; Jamuna, Ashok, \& Palanivel, 2009; Kurilovas, Kubilinskiene, et al., 2014). Educational institutions should personalize their learning environment based on the various characteristics of their learners (Kurilovas, Zilinskiene, \& Dagiene, 2014).(Ouf et al., 2017)

- Learner profile that can incorporate learners needs, skills, learning history, and technical details about his/her platform.

- Formal introduction of learning objects can provide learner with precise selection of learning objects (Jankowski, Czaja, \&Dobrzanski, 2007).

\section{Participation and feedback from learners}

Smart learning is personal learning ${ }^{[}($Gros, 2016)(Popescu and Chen, 2017). The current revolution of learning technologies has made possible the personalization of contents and methodologies, depending on multiple individual factors the learners present [Ros, 2018] (Villagrá-Arnedo C. and And, 2018). These factors indicate the students' learning state, their learning style, the way they progress along the learning process, the skills they have and the skills they acquire while they progress.

Based on the above, we must involve students in designing smart learning so that designs are created in accordance with students' self and we must get feedback from students so that the design is in accordance with the conditions and development of students according to the latest conditions.

\section{References}

Broadbent, J., Poon, W.L., 2015. Self-regulated learning strategies \& academic achievement in online higher education learning environments: A systematic review. Internet High. Educ. https://doi.org/10.1016/j.iheduc.2015.04.007

Freigang, S., and Schlenker, L., and Kohler, T., 2018. A conceptual framework for designing smart learning environments. Smart Learn. Environ. 5, 27. https://doi.org/10.1186/s40561-018-0076-8

Gros, B., 2016. The design of smart educational environments. Smart Learn. Environ. 3, 15. https://doi.org/10.1186/s40561-016-0039-X

Ibrahim, O., 2019. Investigating of Hidden Fraudulent Website Dataset with An Alternate Point Of View, in: Science Proceeding Series (SPS). Readers Insight Publisher, pp. 7-9. 


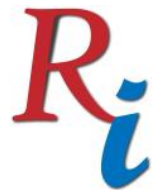

\section{Asia Proceedings of Social Sciences \\ (APSS) \\ www.readersinsight.net/APSS}

Kravcik, M., Popescu, E., 2015. Design of Theoretical Model for Smart Learning, in: Huang, R., Kinshuk, Jemni, M., Chen, N.-S., Spector, J.M. (Eds.), State of The- Art and Future Directions of Smart Learning. Springer, pp. 77-86. https://doi.org/10.1007/978-981-287-868-7

Lister, P.J., 2018. A smarter knowledge commons for smart learning 1-15. https://doi.org/10.1186/s40561-0180056-Z

Ouf, S., Abd Ellatif, M., Salama, S.E., Helmy, Y., 2017. A proposed paradigm for smart learning environment based on semantic web. Comput. Human Behav. 72, 796-818. https://doi.org/10.1016/j.chb.2016.08.030

Popescu, E., Chen, N., 2017. A Conceptual Framework for a Smart Learning Engine, in: Spector, R.H.K.M.J.N.-S.C.J.M. (Ed.), Innovations in Smart Learning. Springer Singapore, p. XIV, 2361245. https://doi.org/10.1007/978-981-10-2419-1

Spector, J., 2016. Smart Learning Environments: Concepts and Issues. ResearchGate Publication, pp. 27272737.

Villagrá-Arnedo C., R., And, M.-C., 2018. Smart Learning, in: The 6th International Conference on Technological Ecosystems for Enhancing Multiculturality (TEEM 2018). García-Peñalvo Ed. ACM, New York, NY, USA, Salamanca, Spain, Spain, pp. 1-3. https://doi.org/10.1145/3284179.3284288 